\title{
Scientific research in tourism: review of the literature from 2005 to 2009*
}

\author{
Mariana de Queiroz Brunelli** \\ T. Diana L. van Aduard de Macedo-Soares*** \\ Deborah Moraes Zouain**** \\ Ana Paula Borges*****
}

Summary: 1. Introduction; 2. Methodology; 3. Results; 4. Conclusions.

SumÁrio: 1. Introdução; 2. Metodologia; 3. Resultados; 4. Conclusões.

KEY WORDs: tourism; literature review; strategy, network perspective.

Palavras-chave: turismo; revisão da literatura; stratégia; perspectiva de rede.

This article presents the results of a review of the literature on tourism from 2005 to 2009. Precisely, 1,648 articles were reviewed and classified into eight macro-lines of research. The content of the Strategy macro-line was analyzed in greater depth, as it was considered to be an "umbrella" for the other dimensions pertinent to tourism. The literature thus provided significant elements confirming the appropriateness of the strategic network perspective for research on sustainable tourism management, and it also helped identify the actors that are most critical for leading the development of a tourist destination.

\footnotetext{
* Article received in May e accepted in Aug. 2010.

** Master student of strategic management. Pontifical Catholic University of Rio de Janeiro (PUCRio/IAG). Address: Rua Piratininga, 30, 302 - Gávea - CEP 22451-130, Rio de Janeiro, RJ, Brazil. E-mail: maribrunelli@gmail.com,

*** PhD. Professor. Pontifical Catholic University of Rio de Janeiro (PUC-Rio/IAG). Address: Av. Marquês de São Vicente, 225 - Gávea - CEP 22453-900, Rio de Janeiro, RJ, Brazil. E-mail: redes@strategy-research.com.br.

**** PhD. Professor. Getulio Vargas Foundation (Ebape/FGV). Address: Praia de Botafogo, 190, $5^{\text {th }}$ floor — Botafogo — CEP 22253-900, Rio de Janeiro, RJ, Brazil. E-mail: deborah.zouain@fgv.br.

******** M.Sc. Getulio Vargas Foundation (Ebape/FGV). Address: Praia de Botafogo, 190, $5^{\text {th }}$ floor — Botafogo — CEP 22253-900, Rio de Janeiro, RJ, Brazil. E-mail: borgean1@hotmail.com.
} 
Pesquisa científica em turismo: revisão da literatura entre 2005 e 2009

Este artigo apresenta os resultados de uma revisão da literatura sobre o turismo de 2005 a 2009. Precisamente, 1.648 artigos foram revistos e classificados em oito macrolinhas de pesquisa. O conteúdo da linha de macroestratégia foi analisado em maior profundidade, já que era um "guarda-chuva" para as outras dimensões pertinentes ao turismo. A literatura, portanto, forneceu elementos significativos confirmando a pertinência da perspectiva de redes estratégicas de investigação sobre a gestão do turismo sustentável, e isso também ajudou a identificar os atores que são mais críticos para liderar o desenvolvimento de um destino turístico.

\section{Introduction}

Over the past six decades, tourism has been one of the world economy's fastest growing sectors. This trend was, however, interrupted in 2009 due to the financial crisis and the Influenza A/H1N1 epidemic. For the first time in many years, the numbers showed a decline in the sector's growth, with international disembarkations expected to have fallen by $6 \%$ in relation to 2008 (UNWTO, 2009).

Although this prospect in no way reduces the economic importance of a sector that generates revenues of around US $\$ 900$ billion a year and accounts for approximately $7 \%$ of global direct and indirect jobs (UNWTO, 2009), the growing social and environmental pressures that have come to the fore during the past decade, have increased the complexity of the challenges faced by the tourism industry's public and private managers.

In the academic sphere, complexity constitutes a powerful stimulus for investigation. The area's researchers have been seeking to develop a more robust theoretical foundation for tourism in order to firmly establish it as an academic discipline. For Cooper et al. (2001), tourism as a field of study still requires a more solid conceptual basis, the lack of which may be attributed to the fact that academic research in the area mirrors the industry's fragmentation and absence of defined structures.

In order to, at least partly, fill the gap identified above, a literature review was undertaken of the articles published on tourism over the past five years. This article presents the most important results of this investigation, the aim of which was to (1) identify and classify macro-lines of research in the tourism area; (2) present the main trends revealed; and (3) perform an indepth analysis of academic output in the tourism area that focuses on strategic issues using a network approach.

Tourism, despite being one of the world economy's most important sectors, has rarely been studied from a strategic network viewpoint (Donaire, 
Silva and Gaspar, 2009). A network approach to the subject is justified by the industry's notoriously multi-sectoral nature, with its series of distinct yet interdependent actors and activities (Tremblay, 1998; Cooper et al., 2001; Barbosa and Zamot, 2004). Thus, the objective of this literature review was not solely to contribute to a greater structuring of scientific research in the field of tourism, but also to the development of the strategy literature in this area.

This article is divided into four sections, including this introduction. The second part explains the methodology adopted for the literature review. The third part presents the review's main results and the fourth part concludes this study and provides suggestions for future research.

\section{Methodology}

The literature review followed the method proposed by Villas, Macedo-Soares and Russo (2008). The authors recommend initiating bibliographical investigations by way of an analysis of scientific journal rankings. Briefly, the method involves three key stages: (1) a survey of the initial sources to be analyzed, based on scientific publication rankings; (2) selection and analysis of articles, listing authors and keywords; (3) selection of new articles based on an analysis of the previously selected documents' bibliographical references.

Increasing the number of steps in relation to the method proposed by Villas, Macedo-Soares and Russo (2008), the present literature review used a five stage procedure detailed below.

\section{Selection of periodicals}

Two rankings of academic periodicals were adopted for the selection of scientific magazines and journals: the Institute for Scientific Information (ISI) system and the so-called "Qualis" ranking system of the Brazilian research funding body, Capes. The review also included journals that are not classified by the ISI and Qualis systems, but which are often cited in the bibliographical references of the articles analyzed.

The research selected 139 journals, as well as six proceedings of congresses that were considered to be an important source regarding the area's research in progress, totaling 145 publications. However, when it was found that articles published in conference proceedings had also been published in scientific journals, they were removed from the literature review to avoid double counting in its database. 


\section{Identification of articles}

Having decided which scientific journals to include, the following step was to select articles that were pertinent to a literature review in the field of tourism. Each selected publication was investigated in virtual databases available through the internet. The research used the keyword "tourism" in the search engines and adopted a "2005-2009" time frame.

1,648 articles were chosen from 56 different journals. A data base listing the articles was created in order to better structure the analysis of the material under investigation.

\section{Classification of articles}

In the data base, each article was classified according to title, author, name of journal, year of publication and related key words. With a view to carrying out an analysis of these articles, it was decided to further classify them according to macro-lines of research using keywords, in accordance with the method proposed by Villas, Macedo-Soares and Russo (2008). The following criteria were adopted for classification purposes:

v After reading each article's abstract, a single word that best represented it was chosen from the complete list of the article's keywords;

- The articles that did not present keywords (a minority) were classified by reading their abstracts;

v The keywords selected were grouped according to the criterion of conceptual proximity, thus establishing thematic axes.

\section{Data bank analysis}

The data bank was analyzed through the use of the simple univariate statistical tool of frequency analysis, identifying the main macro research lines in the tourism area, as well as the main publication trends where academic literature was concerned.

\section{In-depth analysis}

It is important to recall that this article is limited to the results of the in-depth analysis of articles pertinent to the Strategy macro-line of research that adopted a network perspective. 
The research decided to focus on the Strategy macro-line because it was considered to be an "umbrella" that encompasses all the other macro-lines of research identified. Indeed, well formulated strategies will provide a basis for addressing most of the tourism industry's critical issues. In the scope of our research, it was thus contended that the Strategy macro-line of research could provide support for all other dimensions of tourism.

The reason for choosing a network perspective was related to the characteristics of the tourism industry, which depends for its existence on the articulation of a network of actors and businesses for supplying the tourist product.

\section{Results}

\section{Macro-lines of research}

The adoption of the method explained in the previous section resulted in eight macro-lines of research, as shown in figure 1.

Figure 1

Macro-lines of research in tourism and related keywords

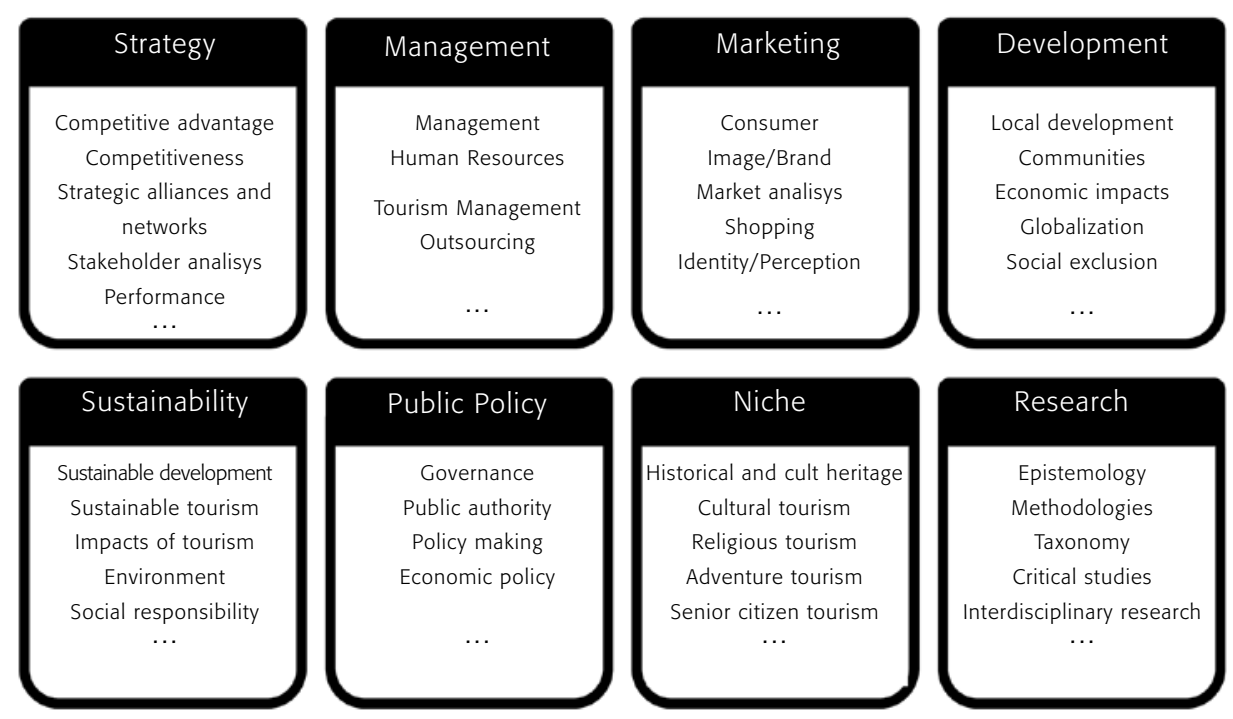

Source: Prepared by the authors. 
The macro-line of research named Strategy was identified from the group of words related to the concept of competitiveness. The Management macro-line resulted from grouping the words that referred to the management of tourist firms and institutions. Marketing was defined as one of the macro-lines to classify research dealing with issues related to consumer (tourist) behavior and destination branding. In the case of the Development macro-line, the grouped keywords were drawn from articles that focused on tourism's impact on the development of host localities. Sustainability was the macro-line of research that congregated the greatest number of articles exploring themes related to the environment and sustainable development. The Public Policies line of research included the articles in which keywords referred to issues related to public sector policies towards tourism. The Niche macro-line was established due to the identification of a large number of articles that dealt with specific tourism segments such as religion and adventure. The Research macro-line emerged from the keywords related to research methodologies and academic research methods in the tourism field.

It should be noted that some of the articles' content may overlap in terms of the macro-lines of research identified, given that some articles employ more than one conceptual approach. For example, some articles classified in Marketing deal with the issue of brand image from a strategic viewpoint and articles can be found in the Sustainability macro-line of research that examine issues related to the development of host communities or mention aspects of public policy.

These examples confirm tourism's status as a multidisciplinary area of study. However, for the purposes of the literature review, it was decided to classify each article under only one macro-line of research. Thus, the classification of articles was based on the choice of a single keyword, in accordance with the criteria mentioned above.

\section{Data bank results}

Based on the analysis of the variables listed in the data bank that were generated from the articles' survey, it was possible to identify the first trends of tourism research undertaken over the past five years. Before presenting them, it should be observed that 16 journals concentrated $95 \%$ of the articles published in the tourism field (table 1). Moreover, only a very small number of articles on tourism were published in traditional scientific administration journals. This may be due to the fact that there are a large number of publications specialized in tourism. 
Table 1

\section{List of the 16 periodicals that published $95 \%$ of the articles surveyed}

\begin{tabular}{|c|c|c|c|c|c|}
\hline Journal & Ranking & Brazil/int. & Tour./bus. & Qty papers & $\%$ \\
\hline Tourism Management & ISI & International & Tourism & 460 & 28 \\
\hline Journal of Travel Research & $|S|$ & International & Tourism & 219 & 13 \\
\hline Annals of Tourism Research & B1 & International & Tourism & 215 & 13 \\
\hline Journal of Vacation Marketing & $|S|$ & International & Tourism & 98 & 6 \\
\hline Turismo. Visão e Ação (Itajaí) & B3 & Brazil & Tourism & 93 & 6 \\
\hline Estudios y Perspectivas en Turismo & B2 & International & Tourism & 80 & 5 \\
\hline $\begin{array}{l}\text { Revista Acadêmica Observatório de } \\
\text { Inovação do Turismo }\end{array}$ & B4 & Brazil & Tourism & 65 & 4 \\
\hline Caderno Virtual do Turismo & B4 & Brazil & Tourism & 61 & 4 \\
\hline Tourism Studies & $|S|$ & International & Tourism & 55 & 3 \\
\hline Revista Global Tourism & B5 & Brazil & Tourism & 53 & 2 \\
\hline $\begin{array}{l}\text { International Journal of Contemporary } \\
\text { Hospitality Management }\end{array}$ & $\mathrm{A} 2$ & International & Tourism & 35 & 2 \\
\hline EnAnpad Congress & $\mathrm{n} / \mathrm{a}$ & Brazil & Business & 34 & 2 \\
\hline Revista Eletrônica de Turismo Cultural & B5 & Brazil & Tourism & 33 & 2 \\
\hline $\begin{array}{l}\text { Patrimônio, Lazer \& Turismo } \\
\text { (Unisantos) }\end{array}$ & B5 & Brazil & Tourism & 31 & 2 \\
\hline Journal of Business Research & $|S|$ & International & Business & 18 & 1 \\
\hline \multirow{2}{*}{$\begin{array}{l}\text { Revista Científica Eletrônica de } \\
\text { Turismo }\end{array}$} & B5 & Brazil & Tourism & 17 & 1 \\
\hline & & & & 1,567 & 95 \\
\hline
\end{tabular}

Although the latter could be considered an indication that tourism as a scientific field is expanding, on the basis of the yearly distribution of articles published it was not possible to affirm that this was the case. Indeed, the analysis of the articles on tourism published per year (figure 2) showed a relatively stable trend in the number published during the period surveyed.

The analysis shows that the Marketing research line possessed the greatest number of articles published (table 2). The Strategy line of research occupied the second position but with less than half the articles classified. It is probable that the large number of articles concentrated in these two lines of research reflect a concern in tourism studies with how to assure touristic demand over time, as this is strategic for the development of tourist destinations and has implications for their marketing. 
Figure 2

\section{Number of articles-year}

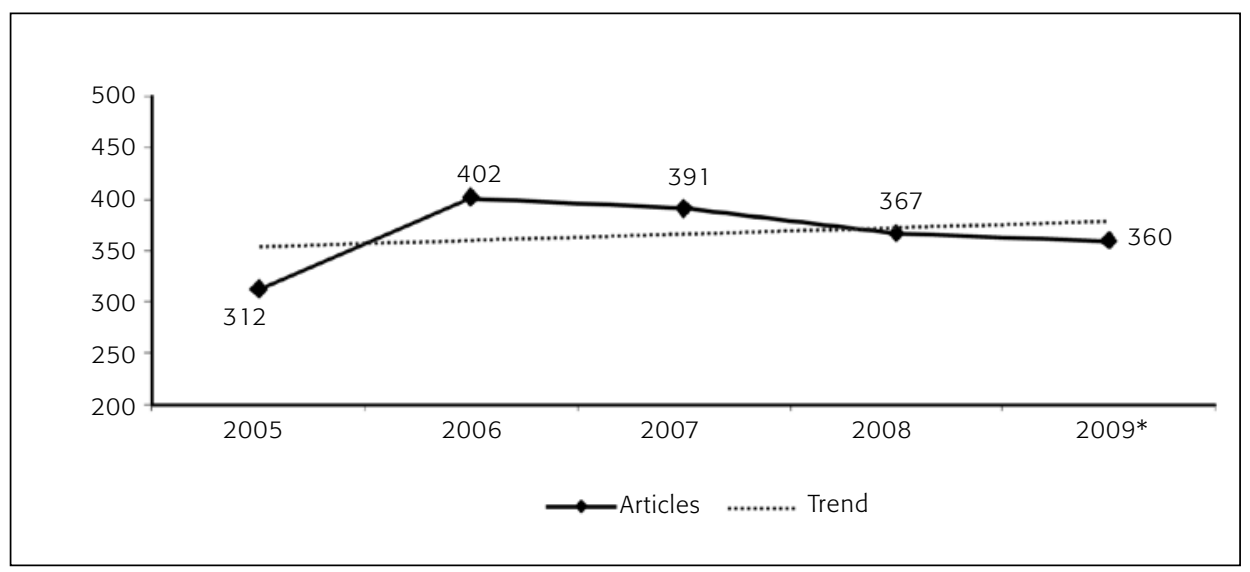

* The examination of the articles in this bibliographical survey ended in July 2009, with 176 articles analyzed during this year. The number presented in the graph is a projection.

Table 2

Number of articles per macro-line of research

\begin{tabular}{|lccccccc|}
\hline Thematic group & 2005 & 2006 & 2007 & 2008 & 2009 & Total & Total (\%) \\
\hline Marketing & 86 & 136 & 147 & 128 & 73 & 569 & 34.5 \\
Strategy & 50 & 54 & 57 & 50 & 23 & 234 & 14.2 \\
Niche & 46 & 51 & 61 & 48 & 23 & 229 & 13.9 \\
Development & 43 & 52 & 43 & 46 & 18 & 202 & 12.3 \\
Sustainability & 32 & 38 & 31 & 37 & 7 & 145 & 8.8 \\
Management & 19 & 40 & 25 & 32 & 18 & 135 & 8.2 \\
Research & 31 & 15 & 17 & 19 & 11 & 93 & 5.6 \\
Public policies & 5 & 16 & 9 & 7 & 4 & 41 & 2.5 \\
Total & 312 & 402 & 391 & 367 & 176 & 1,648 & 100.0 \\
\hline
\end{tabular}

The Marketing and Strategy research lines were followed by the Niche macro-line, indicating that tourism is suited to segmented research. The Development and Sustainability lines of research revealed a growing concern with the issue of how to manage tourism's growth faced with the need to satisfy social and environmental demands. The line classified as Research suggested that methodological questions pertinent to tourism research were as yet not a 
priority. This appeared also to be the case where Public Policies were concerned, as only $2.5 \%$ of the articles focused on this topic.

\section{In-depth analysis results: strategic approach \& network perspective in tourism}

Tremblay (1998) sees the cooperation network perspective as the new organizational paradigm for tourism management. His view is based on an analysis of the characteristics of the tourism industry, which is considered a dynamic system constituted by heterogeneous, interdependent and mostly complimentary activities.

Given tourism's complexity, reflected in the countless gamut of relationships generated by its various stakeholders, we argue here that a linear structure analysis model such as a value chain, for example, can hardly provide the necessary inputs to fully understand the tourist industry. This idea is corroborated by Garrido (2001) when she affirms that the production chain model, with its industrial sector assembly line characteristics, could not be further from the reality of tourism.

Despite the importance attributed by certain authors to the network perspective, the latter approach is still largely ignored by researchers. The literature review at issue here identified only 13 articles which adopted this approach $(0.8 \%$ of the 1,648 articles on tourism analyzed).

The lack of publications pertinent to the network perspective led us to undertake an in-depth analysis of the content of those articles that adopted this perspective. This analysis was carried out according to their contributions regarding (1) their confirmation of the appropriateness of a network perspective for tourism research, and (2) the identification of the tourism macronetwork's main actors.

\section{Appropriateness of the Network Perspective for Tourism}

March and Wilkinson (2009) contend that, in tourism, value is created for customers (tourists) through a complex network of interactions between interdependent actors. Scott, Cooper and Baggio (2008) complement this idea by defining that a tourist destination is composed of a group of independent suppliers who are articulated spontaneously to deliver the tourist product. In this context, the tourist destination's products are produced by adding di- 
fferent elements at the moment of their consumption in order to provide the customer's total experience (Wang and Krakover, 2008).

In sharp contrast to manufacturing industry, which delivers finished products to markets, tourism distributes customers to places where services are produced (Grangsjo and Gummerson, 2006). For Grangsjo and Gummerson (2006), this basic prerequisite affects a destination's marketing strategies and competitor network, as the services are partly delivered in an interaction with customers. This characteristic of tourism makes it necessary to develop cooperative relations between firms and organizations to join resources and develop a mutual commitment, with the common objective of attracting more visitors to the destination (Wang and Krakover, 2008). In a similar vein, Scott et al. (2008) argue that tourism, more than other economic sectors, depends on the formal and informal development of collaborative relations, partnerships and networks.

The motivations behind collaborative relationships in tourism can vary substantially and their objectives can be economic, strategic and social or learning related (Wang and Fesenmaier, 2007). When these relationships form a cooperative network, firms obtain competitive advantages through sharing knowledge, resources, markets and technologies (Novelli, Schimitz and Spencer, 2006; Scott et al., 2008; Timur and Getz, 2008; Guimarães et al., 2008; March and Wilkinson, 2009). Another important role of these networks is to minimize transaction costs and exploit scale and scope economies, sharing risks and providing access to complementary resources (Erkus-Ozturk, 2009).

Grangsjo and Gummerson (2006) similarly argue that the creation of a network of local competitors may contribute to improving each firm's individual situation when the collective actions undertaken lead to an improvement in the destination's competitive position in the market. Following this approach, Wang and Krakover (2009) affirm that three different types of relationships coexist between tourism's stakeholders: cooperation, competition and co-opetition - a concept originally proposed by Brandenburger and Nalebuff in 1996.

Cooperation, according to Wang and Krakover (2009), is important to assure the most efficient use of a destination's limited resources. Competition, on the other hand, is important to motivate each separate business. Co-opetition may constitute an efficient way of dealing with both the cooperation and competition necessary for the development of tourist sector business. Thus the creation of a network is facilitated when local competitors build their social capital through trust and commitment and observe certain basic principles, such as acting in accordance with a collectively drawn up code of conduct (Grangsjo and Gummerson, 2006). 
A cooperation network's success may lead firms to develop more formal relationships such as strategic alliances in order to share or co-develop products and services (Novelli et al., 2006). Among the strategic alliances that are most pertinent to tourism, Pansiri (2008) highlights joint ventures, asset sharing, brand, franchise and license sharing, marketing and distribution agreements, joint sales and distribution, information and technology sharing, joint purchasing agreements and equipment sharing. For Novelli et al. (2006), strategic alliances generate an improvement in service quality, increase the visibility of destinations and open up opportunities for cross marketing activities with other groups of firms.

Wang and Krakover (2009) contend that the fragmentation and complexity of the tourism industry make a collaborative approach for this sector an imperative. Scott et al. (2008) also argue that the analysis of tourism's relationship network structures reveals important information regarding the competitiveness of tourist destinations, by providing significant insights that contribute to a destination's communication, planning and decision-making process. This argument is echoed by Shih (2006:1038) when he declares that "the analysis of networks is an appropriate tool for investigating the structural characteristics of a tourist destination". Moreover, Timur and Getz (2008) defend the use of a network perspective in the tourism industry, recognizing that a tourist destination is a system that consists of relations that can influence the opportunities, restrictions, behavior and values of the actors involved in it.

The views of the authors presented in this section strongly suggest that the network perspective is particularly appropriate for conducting research in a multidisciplinary sector such as tourism. By enabling the analysis of not only its structure but also its interconnections, this perspective contributes to a deeper understanding of the sector (Scott et al., 2008). Indeed, it can reveal relational opportunities and threats, as well as a shed new light on a destination's strengths and weaknesses. The gaining of new insights that are pertinent to tourism's network of relationships can also help increase the effectiveness of the sector's actors/firms in terms of contributing to the sustainable development of tourist destinations.

\section{Main actors of the tourism macro-network}

The network perspective has been used in tourism research to identify the network's main stakeholders, examine the interactions between them or the function of the network as a whole (Timur and Getz, 2008). Following the first line 
of research identified by Timur and Getz (2008), this article sought, amongst other objectives, to confirm which are the tourism network's most important actors, according to the literature review undertaken.

The tourism network's main actors are those identified as occupying a more central position in the group of touristic firms and organizations. A high level of centrality in the network enables the actors to manage information flows and influence other actors, thus endowing them with a strategic advantage (Timur and Getz, 2008). Moreover, in the light of the concepts of stakeholder theory, Timur and Getz (2008) show that the identification of actors that are critical to tourism's development is related to the analysis of two fundamental attributes: the power and legitimacy exercised by them in relation to other tourism network actors.

According to Scott et al. (2008), the tourism network's main actors are those with a wider interest in the issues affecting a particular destination. They are the largest firms with revenues from various sectors of the market and are involved in more than one community of interest in the destination, such as big hotels and airlines.

The following occupy an especially important place among the tourism network's main actors: Destination Management Organizations (DMOs, such as the Convention \& Visitors Offices), hotels, tourist transportation firms, travel agencies, government agencies, tourist operators and event organizers, as well as tourist attractions (Timur and Getz, 2008; Donaire et al., 2009; March and Wilkinson, 2009). The special place attributed to several of these actors is partly confirmed by the data presented in the World Tourism Organization's annual report (UNWTO, 2009) indicating that tourists' expenditures on lodging, food and drink, local transportation/transport, entertainment and purchases are the most important sources of revenue for the economy and development of many tourist destinations.

It is important to highlight the tourism network's main actors because of the responsibility attributed to these agents. These include the communication of the destination's development planning, the mediation to facilitate collaboration between stakeholders, the growing need to create awareness among network members regarding socio-environmental issues and the coordination of efforts to attain the tourist industry's collective targets (Timur and Getz, 2008). Thus, in order to understand how the tourism network as a whole functions, it appears to be fundamental to investigate the relationship network from each actor's viewpoint, analyzing how each of them manages it.

With respect to the latter, it is noteworthy that the research identified only one article whose proposal was to analyze the relationship network of 
each tourist system actor. Silva and Teixeira's (2007) study analyzes the case of a hotel in the city of Curitiba in the south of Brazil. As it is a unique case study of an exploratory nature, it is not possible to generalize its results. However the finding regarding the fact that the managers of this particular hotel did not possess a strategic view of inter-organizational relationships indicated a lack of awareness regarding the advantages they could derive from this perspective.

\section{Conclusions}

In summary, the study at issue in this article was motivated by the identification of a lack of solid theoretical bases in academic research on tourism (Cooper et al., 2001). Its objective was to at least partly fill this gap by carrying out a literature review of scientific articles on tourism published between 2005 and 2009. Its aims were three-fold: (1) to identify and classify macro-lines of research in the field of tourism; (2) present the main trends encountered; (3) undertake an in-depth analysis of the academic production on tourism focused on strategic issues with a network approach.

As also already mentioned, in accordance with the methodology adopted, 1,648 articles from 56 different scientific journals were examined, and based on the grouping of their keywords eight macro-lines of research in tourism were identified: Marketing, Strategy, Niche, Development, Sustainability, Management, Research and Public Policies.

In keeping with the contention that the Strategy macro-line of research was an "umbrella" for the other dimensions of tourism, the research undertook an in-depth analysis of the articles classified in this macro-line. Due to limitations of time and space, priority was given to articles which adopted a network perspective. This choice was justified by the fact that the tourism sector's very existence depends on the articulation of a network of actors and businesses aimed at supplying the tourist product. These articles' content was analyzed in order to assess the contribution of the network perspective in tourism and identify the tourism network's main actors.

In terms of achieving its objectives, the literature review provided significant elements confirming the appropriateness of a network perspective for research in the tourism area, namely the fact that this perspective enables a deeper understanding of this sector by offering a framework for an analysis of its structure and interconnections. By the same token, it suggested that the insights gleaned from this perspective could contribute to a more effective per- 
formance on the part of this sector's actors/firms, in terms of levering tourist destination's sustainable development.

However, on the whole, the literature review confirmed that there was a dearth of studies on the advantages that tourism sector managers could obtain by using a strategic network perspective.

We thus recommend further investigations in the strategy macro line of research from this perspective, for example, on how each actor / stakeholder in the network can add value to effective tourism destination management oriented towards sustainable socioeconomic development.

We also suggest that in-depth analyses be conducted of the literature pertinent to the other relevant macro-lines of tourism research identified in our study, considering the strategy macro-line as an umbrella for the other lines, with a view to deepening the understanding of this increasingly important industry within a systemic strategic network perspective.

\section{References}

BARBOSA, Luiz Gustavo M.; ZAMOT, Fuad. S. Políticas públicas para o desenvolvimento do turismo: o caso do município de Rio das Ostras. In: BARBOSA, Luiz Gustavo M.; ZOUAIN, Deborah M. (Orgs.). Gestão em turismo e hotelaria: experiências públicas e privadas. São Paulol: Aleph, 2004.

BRANDENBURGER, Adam M.; NALEBUFF, Barry J. Co-opetition. New York: Dobleday, 1996.

COOPER, Chris et al. Turismo: princípios e práticas. 2. ed. Porto Alegre: Bookman, 2001.

CUSTÓDIO, Denise V. A importância do planejamento urbano-ambiental para o crescimento sustentável do setor turístico. In: BARBOSA, Luiz Gustavo M.; ZOUAIN, Deborah M. (Orgs.). Gestão em turismo e hotelaria: experiências públicas e privadas. São Paulo, Brasil: Aleph, 2004.

DONAIRE, Denis; SILVA, Marcos P.; GASPAR, Marcos A. A rede de negócios do turismo: um estudo sobre duas características e implicações estratégicas. Revista Turismo Visão e Ação — Eletrônica, v. 11, n. 1, p. 112-134, 2009.

GARRIDO, Inez M. D. A. Modelos multiorganizacionais no turismo: cadeias, clusters e redes. 2001. Masters (Disseration) - Department of Administration. Federal University of Bahia. Salvador, Brazil, 2001.

GRANGSJO, Yvonne v. F.; GUMMESSON, Evert. Hotel networks and social capital in destination marketing. International Journal of Service Industry Management, v. 17, n. 1, p. 58-75, 2006. 
GUIMARÃES, Antônio T. R. et al. O caso dos hotéis da Associação Roteiros de Charme: competir e vencer como em rede de negócios? In: TECHNOLOGICAL INNOVATION MANAGEMENT SYMPOSIUM, 25., 2008, Brasília. Anals... 2008.

MARCH, Roger; WILKINSON, Ian. Conceptual tools for evaluating tourism partnerships. Tourism Management, n. 30, p. 455-462, 2009.

NOVELLI, Marina; SCHIMITZ, Birte; SPENCER, Trisha. Networks, clusters and innovation in tourism: a UK experience. Tourism Management, n. 27, p. 1141-1152, 2006.

OZTURK-ERKUS, Hilal. The role of cluster types and firm size in designing the level of network relations: the experience of the Antalya region. Tourism Management, n. 30, p. 589-597, 2009.

PANSIRI, Jaloni. The effects of characteristics of partners on strategic alliance performance in the SME dominated travel sector. Tourism Management, n. 29, p. 101-115, 2008.

SCOTT, Noel; COOPER, Chris; BAGGIO, Rodolfo. Destination networks: four Australian cases. Annals of Tourism Research, v. 35, n. 1, p. 169-188, 2008.

SILVA, Antônio J. H.; TEIXEIRA, Rivanda M. Ambiente competitivo e obtenção de vantagens competitivas a partir de uma abordagem integradora: estudo de caso no setor hoteleiro em Curitiba. REAd, ed. 55, v. 13, n. 1, 2007.

SHIH, Hsin-Yu. Network characteristics of drive tourism destinations: an application of network analysis in tourism. Tourism Management, n. 27, p. 1029-1039, 2006.

TIMUR, Seldjan; GETZ, Donald. A network perspective on managing stakeholders for sustainable urban tourism. International Journal of Contemporary Hospitality Management, v. 20, n. 4, p. 445-461, 2008.

TREMBLAY, Pascal. The economic organization of tourism. Annals of Tourism Research, v. 25, n. 4, p. 837-859, 1998.

UNWTO (United Nations World Tourism Organization). Tourism highlights. PDF. 2009

VILLAS, Marcos V.; MACEDO-SOARES, Teresia Diana L. V. A.; RUSSO, Giuseppe. M. Bibliographical research method for business administration studies: a model based on scientific journal ranking. Brazilian Administration Review (BAR), v. 5, n. 2, p. 139-159, 2008.

WANG, Youcheng; FESENMAIER, Daniel R. Collaborative destination marketing: a case study of Elkhart county, Indiana. Tourism Management, n. 28, p. 863-875, 2007. 
; KRAKOVER, Shaul. Destination marketing: competition, cooperation or coopetition? International Journal of Contemporary Hospitality Management, v. 20, n. 2 , p. $126-141,2008$.

ZOUAIN, Deborah M.; CRUZ, Francisca O. Gestão social no sistema turístico brasileiro: limites e possibilidades. In: BARBOSA, Luiz Gustavo M.; ZOUAIN, Deborah M. (Orgs.). Gestão em turismo e hotelaria: experiências públicas e privadas. São Paulo: Aleph, 2004. 